\title{
PERSEPSI BANK SYARIAH INDONESIA DI KALANGAN MAHASISWA
}

\author{
Oleh: \\ RASIVA NADILA \\ Rasifanadila2019@gmail.com
}

\begin{abstract}
Abstrak
Indonesia adalah negara dengan populasi muslim terbanyak di dunia. Dengan lebih dari 207,2 juta muslim berdasarkan data dari statistik nasional, BPS (2010), ini setara dengan $87,5 \%$ dari seluruh total populasi. Fenomena umum bank syariah saat ini adalah pengaruh dari beberapa faktor salah duanya biaya dana yang tinggi menghasilkan segmen pembiayaan terbatas dan fasilitas pelayanan. Penelitian ini bertujuan untuk mengetahui apakah bank syariah memiliki sistem bagi hasil yang lebih menguntungkan bagi nasabah (dibandingkan bank konvensional). Selai itu, penelitian ini juga bertujuan untuk mengetahui apakah bank syariah telah memiliki fasilitas ATM yang memadai.
\end{abstract}

Kata kunci: Perbankan syariah, uji komparasi, persepsi konsumen 


\section{BAB I \\ PENDAHULUAN}

\subsection{LATAR BELAKANG}

Indonesia adalah negara dengan populasi muslim terbanyak di dunia. Dengan lebih dari 207,2 juta muslim berdasarkan data dari statistik nasional, BPS (2010), ini setara dengan $87,5 \%$ dari seluruh total populasi. Meskipun kelihatannya negara ini memiliki potensi pengembangan yang lebih jauh terhadap industri perbankan syariah, fakta menunjukan bahwa pada syarat-syarat pangsa pasar, total aset dari industri perbankan syariah negara masih berada dibawah 5\% pada akhir 2014 setelah lebih dari dua dekade operasi.

Kehadiran bank syariah pertama di Indonesia pertama kali dipelopori oleh Bank Muammalat Indonesia pada 1991 berdasarkan inisiatif oleh Majelis Ulama Indonesia (MUI) yang memenuhi prinsip-prinsip islam. Perbedaan mendasar antara bank konvensional dengan bank syariah berada pada tingkat bunga atau riba yang mana hal tersebut dilarang dalam bank syariah. Lebih daripada itu, investasi hanya diperbolehkan untuk bisnis-bisnis yang berkategori halal. Adapun sistem bagi hasil yang menjadi prinsip dasar operasi perbankan syariah yang mana tidak dapat disediakan oleh bank konvensional. Fenomena umum bank syariah saat ini adalah pengaruh dari beberapa faktor salah duanya biaya dana yang tinggi menghasilkan segmen pembiayaan terbatas dan fasilitas pelayanan.

\subsection{RUMUSAN MASALAH}

1. Apakah Bank Syariah memiliki sistem bagi hasil yang lebih menguntungkan bagi nasabah (dibandingkan Bank Konvensional)?

2. Apakah Bank Syariah telah memiliki fasilitas ATM yang memadai?

\subsection{TUJUAN PENULISAN}

1. Untuk mengetahui apakah bank syariah memiliki sistem bagi hasil yang lebih menguntungkan bagi nasabah (dibandingkan bank konvensional).

2. Untuk mengetahui apakah bank syariah telah memiliki fasilitas ATM yang memadai. 


\section{BAB II}

\section{LANDASAN TEORI}

\subsection{PENGERTIAN BANK SYARIAH}

Bank pada dasarnya adalah entitas yang melakukan penghimpunan dana dari masyarakat dalam bentuk pembiayaan atau dengan kata lain melakukan fungsi intermediasi keuangan. Dalam sistem perbankan di Indonesia terdiri dari dua macam sistem operasional perbankan, yaitu bank konvensional dan bank syariah.

Sesuai dengan UU no. 21 tahun 2008 tentang Perbankan Syariah, Bank Syariah adalah bank yang menjalankan kegiatan usaha berdasarkan prinsip syariah atau prinsip hukum Islam yang diatur dalam fatwa Majelis Ulama Indonesia (MUI) seperti prinsip keadilan dan keseimbangan ('adl wa tawazun), kemaslahatan (maslahah), universalisme (alamiyah), serta tidak mengandung gharar, maysir, riba, zalim, dan obyek yang haram.

Selain itu, UU perbankan syariah juga mengamankan bank syariah untuk menjalankan fungsi sosial dengan menjalankan fungsi seperti lembaga baitul mal, yaitu menerima dana yang berasa dari zakat, infak, sedekah, hibah, atau dana sosial lainnya dan menyalurkannya kepada pengelola wakaf (nazhir)sesuai kehendak pemberi wakaf (wakif)

\subsection{PERBEDAAN BANK SYARIAH DENGAN BANK KONVENSIONAL}

Perbedaan mendasar antara bank-bank Islam dan konvensional adalah bahwa mereka dianggap sah (halal) dalam Islam. Sistem bagi hasil, yang merupakan prinsip dasar perbankan Islam, tidak ditemukan dalam sistem perbankan konvensional, yang justru menghasilkan laba dan membayar bunga. Akibatnya, motif agama prinsipprinsip Islam dan sistem pembagian laba dan rugi dapat dianggap sebagai faktor dominan yang dipertimbangkan oleh pelanggan ketika memilih bank Islam (Amin et al., 2013).

Bila digambarkan pada tabel, secara garis besar hal-hal yang memberdakan antara bank konvensional dengan bank syariah adalah sebagai berikut: 


\begin{tabular}{|c|c|c|}
\hline NO & Bank Konvensional & Bank Syariah \\
\hline 1 & Bebas nilai & Berinvestasi pada usaha yang halal saja \\
\hline 2 & Sistem bunga & $\begin{array}{l}\text { Atas dasar bagi hasil, margin keuntungan } \\
\text { dan fee }\end{array}$ \\
\hline 3 & Besar bunga tetap & $\begin{array}{l}\text { Besaran bagi hasil berubah-ubah } \\
\text { tergantung kinerja usaha }\end{array}$ \\
\hline 4 & Profit oriented (kebahagiaan dunia saja) & $\begin{array}{l}\text { Profit dan falah oriented (kebahagiaan } \\
\text { dunia dan akhirat) }\end{array}$ \\
\hline 5 & Hubungan debitur-kreditur & $\begin{array}{l}\text { Pola Hubungan: } \\
\text { 1. Kemitraan (musyarakah dan } \\
\text { mudharabah) } \\
\text { 2. Penjual - pembeli (murabahah, salam, } \\
\text { dan istishna) } \\
\text { 3. Sewa menyewa (ijarah) } \\
\text { 4. Debitur - kreditur; dalam artian equity } \\
\text { holder (qard) }\end{array}$ \\
\hline 6 & $\begin{array}{c}\text { Tidak ada lembaga sejenis dengan Dewan } \\
\text { Pengawas Syariah (DPS) }\end{array}$ & Ada Dewan Pengawas Syariah (DPS) \\
\hline
\end{tabular}




\section{BAB III}

\section{METODE}

\subsection{RESPONDEN}

Responden atau objek penelitian peneliti ialah 15 orang Mahasiswa di Indonesia yang pernah atau sedang menjadi nasabah di beragam Bank Syariah Indonesia.

Dibedakan berdasarkan gender, responden tersebut terbagi menjadi 7 orang laki-laki dan 8 orang perempuan yang kerap melakukan transaksi melalui berbagai Bank Syariah ternama di Indonesia.

\subsection{TEKNIK PENGUMPULAN DATA}

Teknik pengumpulan data adalah teknik atau cara yang dilakukan oleh peneliti untuk mengumpulkan data. Metode pengumpulan data ini dapat digunakan secara sendiri-sendiri, namun dapat pula digunakan dengan menggabungkan dua metode atau lebih.

Teknik pengumpulan data yang peneliti gunakan dalam makalah ini adalah penggabungan dari beberapa metode, yakni sebagai berikut;

\section{Angket (Kuisioner)}

Kuesioner merupakan metode pengumpulan data yang dilakukan dengan cara memberi seperangkat pertanyaan atau pernyataan tertulis kepada responden untuk dijawab. Berdasarkan bentuk pertanyaannya, kuisioner yang peneliti gunakan ialah;

- Kuesioner semi terbuka, dimana pilihan jawaban telah diberikan oleh peneliti (skala 1: sangat tidak setuju, sampai 7: sangat setuju), namun objek penelitian tetap diberi kesempatan untuk menjawab (memberikan pendapat) sesuai dengan kemauan mereka.

\section{Studi Dokumen}

Studi dokumen adalah jenis pengumpulan data yang meneliti berbagai macam dokumen yang berguna untuk bahan analisis. Dokumen yang peneliti gunakan dalam makalah ini ada dua, yakni;

- Dokumen primer, yaitu dokumen yang ditulis oleh orang yang langsung mengalami suatu peristiwa, misalnya: autobiografi 
- Dokumen sekunder, yaitu dokumen yang ditulis berdasarkan oleh laporan/ cerita orang lain, misalnya: biografi, jurnal, artikel, buku, dsb.

\subsection{TEKNIK ANALISIS DATA}

Teknik analisis data yang peneliti gunakan dalam makalah ini ialah one sample t-test dan independent sample t-test yang dilakukan pada software SPSS.

"Menurut Setiawan (2015) teknik 1-sample t-test dan independent sample ttest pada SPSS dilakukan melalui fitur Analyze-Compare Mean”. Dijelaskan oleh Setiawan (2013), nilai mean (rata-rata) merupakan salah satu bagian dari analisis ukuran pemusatan data.

\section{Uji T Satu Sampel (One-Sample T Test)}

Uji T satu sampel digunakan untuk membandingkan dua nilai rata-rata apabila nilai parameternya tidak diketahui, dan kita hanya mengambil nilai statistik dari sampel uang digunakan. Syarat penggunaan metode ini adalah; (1) Simpangan baku populasi tidak diketahui, (2) Skala pengukurannya rasio / interval, dan (3) Datanya berdistribusi normal.

$$
t=\frac{x-\mu_{o}}{s / \sqrt{n}}
$$

2. Uji T Sampel Bebas (Independent-Sample T Test)

Uji T sampel bebas dapat digunakan untuk mengetes signifikansi beda ratarata dua kelompok. Selain itu, uji ini juga dapat digunakan untuk mengetes pengaruh variabel bebas terhadap variabel terikat. Pada umumnya, kelompokkelompok dalam uji t dua sampel ditetapkan oleh desain, dan variabel pengelompokannya memiliki satu nilai untuk setiap kelompok.

\section{Rumus dari independent sample t test, yaitu...}

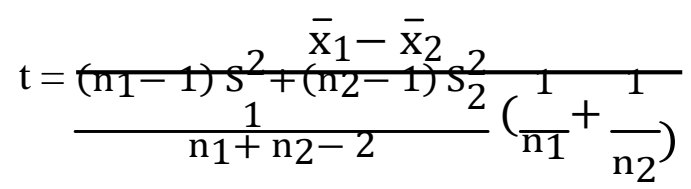




\section{BAB IV}

\section{HASIL}

\subsection{GAMBARAN SINGKAT KARAKTERISTIK RESPONDEN}

Dibawah ini adalah tabel berisi gambaran singkat karakteristik responden yang menjadi objek penelitian berdasarkan data yang diperoleh dengan menanyakan dua pertanyaan berikut;

Q1 : Apakah Bank Syariah memiliki sistem bagi hasil yang lebih menguntungkan bagi nasabah (dibandingkan Bank Konvensional)?

Q2 : Apakah Bank Syariah telah memiliki fasilitas ATM yang memadai?

Lalu dijawab dalam skala 1-7, dimana skala 1 berarti sangat tidak setuju dan skala 7 berarti sangat setuju.

\begin{tabular}{|c|c|c|c|c|c|c|}
\hline NO & NAMA & STATUS & GENDER & $\begin{array}{c}\text { PENGHASILAN } \\
\text { PER BULAN }\end{array}$ & Q1 & Q2 \\
\hline 1 & Raka Zulfikar & Mahasiswa & Laki-Laki & Rp. 800.000 & 5 & 7 \\
\hline 2 & Achmad Maulana & Mahasiswa & Laki-Laki & Rp. 2.500 .000 & 7 & 6 \\
\hline 3 & Guruh Mah Bintang & Mahasiswa & Laki-Laki & Rp. 3.000.000 & 5 & 6 \\
\hline 4 & Fathurrachman & Mahasiswa & Laki-Laki & Rp. 1.000 .000 & 6 & 5 \\
\hline 5 & M. Ridwan Julianto & Mahasiswa & Laki-Laki & Rp. 3.000.000 & 1 & 6 \\
\hline 6 & Fauzan Algifari & Mahasiswa & Laki-Laki & Rp. 1.000 .000 & 5 & 4 \\
\hline 7 & Yoga Rizky Putra & Mahasiswa & Laki-Laki & Rp. 1.500 .000 & 2 & 6 \\
\hline 8 & Nur Rachmatiyah & Mahasiswa & Perempuan & Rp. 2.000 .000 & 3 & 2 \\
\hline 9 & Yuni Arsitawarti & Mahasiswa & Perempuan & Rp. 800.000 & 4 & 2 \\
\hline 10 & Rafika Della & Mahasiswa & Perempuan & Rp. 600.000 & 7 & 2 \\
\hline 11 & Isnaeni Nur Islami & Mahasiswa & Perempuan & Rp. 1.000 .000 & 6 & 7 \\
\hline 12 & Dini Lestari & Mahasiswa & Perempuan & Rp. 1.050 .000 & 6 & 7 \\
\hline 13 & Rasiva Nadila & Mahasiswa & Perempuan & Rp. 1.000 .000 & 4 & 4 \\
\hline 14 & Winda Damayanti & Mahasiswa & Perempuan & Rp. 3.000.000 & 7 & 7 \\
\hline 15 & Eki Nurohmah & Mahasiswa & Perempuan & Rp. 3.000.000 & 4 & 2 \\
\hline
\end{tabular}




\subsection{HASIL ANALISIS DATA}

\section{Uji T Satu Sampel (One-Sample T Test)}

Dengan menggunakan metode ini, peneliti akan menduga rata-rata penghasilan perbulan dari ke-15 responden yang menjadi objek penelitian.

Hipotesis ujinya adalah;

Ho : rata-rata penghasilan responden adalah paling tinggi Rp. 600.000 tiap bulannya.

Ha : rata-rata penghasilan responden adalah lebih dari Rp. 600.000 tiap bulannya.

Setelah dilakukan pengujian melalui SPSS, didapat hasil sebagai berikut;

\begin{tabular}{|l|r|r|r|r|}
\hline & N & Mean & Std. Deviation & Std. Error Mean \\
\hline Penghasilan & 15 & 1683333,33 & 953876,801 & 246289,931 \\
\hline
\end{tabular}

\begin{tabular}{|c|c|c|c|c|c|c|}
\hline \multicolumn{7}{|c|}{ One-Sample Test } \\
\hline & \multicolumn{6}{|c|}{ Test Value $=600000$} \\
\hline & \multirow[b]{2}{*}{$t$} & \multirow[b]{2}{*}{ df } & \multirow{2}{*}{$\begin{array}{l}\text { Sig. (2- } \\
\text { tailed) }\end{array}$} & \multirow{2}{*}{$\begin{array}{c}\text { Mean } \\
\text { Difference }\end{array}$} & \multicolumn{2}{|c|}{$\begin{array}{c}95 \% \text { Confidence Interval of } \\
\text { the Difference }\end{array}$} \\
\hline & & & & & Lower & Upper \\
\hline Penghasilan & 4,399 & 14 & ,001 & 1083333,333 & 555093,97 & 1611572,70 \\
\hline
\end{tabular}

Untuk dapat menguji hipotesis, kita perlu memperhatikan perolehan nilai probabilitas atau Sig. (2-tailed). Ketentuan pengujian hipotesisnya adalah sebagai berikut.

1. Nilai Sig. > a $(0,05)$, keputusannya adalah terima Ho

2. Nilai Sig. < a $(0,05)$, keputusannya adalah tolak Ho

Mengacu pada perolehan nilai sig. Sebesar 0,001, lebih kecil dari 0,05, keputusannya adalah tolak Ho, yakni rata-rata penghasilan responden lebih dari Rp. 600.000 per bulan. 


\section{Uji T Sampel Bebas (Independent-Sample T Test)}

Dengan menggunakan metode ini, peneliti akan menduga berdasarkan perbedaan gender dari ke-15 responden yang menjadi objek penelitian dikaitkan dengan persepsi mereka akan kedua pertanyaan peneliti.

Hipotesis ujinya adalah;

Ho : Tidak Terdapat perbedaan persepsi yang signifikan antara laki-laki dan perempuan mengenai Bank Syariah di Indonesia.

Ha : Terdapat perbedaan persepsi yang signifikan antaralaki-laki dan perempuan mengenai Bank Syariah di Indonesia.

Setelah dilakukan pengujian melalui SPSS, didapat hasil sebagai berikut;

\begin{tabular}{|r|l|r|r|r|r|}
\hline \multicolumn{2}{|c|}{ Group Statistics } \\
\hline \multirow{2}{*}{ Persepsi } & Gender & N & Mean & Std. Deviation & Std. Error Mean \\
& 1 & 14 & 5,07 & 1,730 &, 462 \\
& 2 & 16 & 4,63 & 2,062 &, 515 \\
\hline
\end{tabular}

Independent Samples Test

\begin{tabular}{|c|c|c|c|c|c|c|c|c|c|c|}
\hline & & \multicolumn{2}{|c|}{$\begin{array}{l}\text { Levene's Test for Equality of } \\
\text { Variances }\end{array}$} & \multicolumn{7}{|c|}{ t-test for Equality of Means } \\
\hline & & \multirow[b]{2}{*}{$\mathrm{F}$} & \multirow[b]{2}{*}{ Sig. } & \multirow[b]{2}{*}{$t$} & \multirow[b]{2}{*}{ df } & \multirow[b]{2}{*}{ Sig. (2-tailed) } & \multirow{2}{*}{$\begin{array}{c}\text { Mean } \\
\text { Difference }\end{array}$} & \multirow{2}{*}{$\begin{array}{l}\text { Std. Error } \\
\text { Difference }\end{array}$} & \multicolumn{2}{|c|}{$\begin{array}{l}\text { 95\% Confidence Interval of the } \\
\text { Difference }\end{array}$} \\
\hline & & & & & & & & & Lower & Upper \\
\hline Persepsi & $\begin{array}{l}\text { Equal variances } \\
\text { assumed }\end{array}$ & 2,758 & , 108 & ,637 & 28 &, 529 & 446 &, 701 &,- 989 & 1,882 \\
\hline & $\begin{array}{l}\text { Equal variances not } \\
\text { assumed }\end{array}$ & & & 645 & 27,963 &, 524 & ,446 &, 692 &,- 972 & 1,865 \\
\hline
\end{tabular}

Untuk dapat menguji hipotesis, kita perlu memperhatikan perolehan nilai probabilitas atau Sig. (2-tailed). Ketentuan pengujian hipotesisnya adalah sebagai berikut.

3. Nilai Sig. > a $(0,05)$, keputusannya adalah terima Ho

4. Nilai Sig. < a $(0,05)$, keputusannya adalah tolak Ho

Mengacu pada perolehan nilai sig. Sebesar 0,108, lebih besar dari 0,05, keputusannya adalah terima Ho, yakni tidak terdapat perbedaan persepsi yang signifikan antara laki-laki dan perempuan mengenai Bank Syariah di Indonesia. 


\section{BAB V}

PENUTUP

\subsection{KESIMPULAN}

Pada makalah ilmiah ini, dibuktikan bahwa persepsi bank syariah indonesia di kalangan mahasiswa terkait sistem bagi hasil dan fasilitas ATM yang memadai tidak terdapat perbedaan yang signifikan antara mahasiswa laki-laki dan perempuan. Selain itu, mereka juga memiliki rata-rata penghasilan lebih dari Rp. 600.000 tiap bulannya, yang mana menunjukan bahwa kebanyakan dari mereka biasa bertransaksi dengan bank syariahnya.

Terkait dengan persepsi sistem bagi hasil pada poin Q1, dengan rata-rata 4.8, menunjukan bahwa rata-rata responden cukup setuju bank syariah memiliki sistem bagi hasil yang lebih menguntungkan bagi nasabah. Melihat keuntungan yang mereka perhitungkan, bukan hanya keuntungan dunia saja, melainkan dunia akhirat, dimana dapat menjauhi riba mampu menjadi keuntungan tersendiri bagi mereka. Namun disisi lain, menurut beberapa nasabah nominal bagi hasil yang dimaksud kebijakan bank syariah di Indonesia dirasa kurang begitu profitable.

Adapun terkait dengan persepsi fasilitas ATM bank syariah yang memadai pada poin Q2, dengan rata-rata 4.9, menunjukan bahwa rata-rata responden cukup setuju bank syariah telah memiliki fasilitas ATM yang memadai. Meskipun tidak sebanyak ATM bank konvensional, saat ini beberapa bank negara (Himbara), seperti BNI, Mandiri, dan BRI, telah memfasilitasi ATM yang dapat diakses untuk BNI Syariah, Bank Syariah Mandiri, dan BRI Syariah, khususnya transaksi setor-transfer BNI Syariah melalui ATM BNI konvensional kini tidak dikenakan biaya administrasi. Selain itu, kalangan mahasiswa juga terbantu dengan fasilitas ATM Link dan ATM Bersama yang mana menyediakan fasilitas tarik tunai gratis untuk beberapa bank syariah ternama tersebut. Kendatipun begitu, menurut beberapa responden, justru bank syariah murni seperti bank muamalat masih kekurangan fasilitas ATM yang menjadikannya agak kurang diminati bagi para calon nasabah. 


\section{DAFTAR PUSTAKA}

Mei, Aslam., Marimin., Fahmi, Idqan., and Syauqi, Irfan. (2016). How Islamic is Islamic Banking in Indonesia?. JKAU: Islamic Economy. http://iei.kau.edu.sa

Sari, Mutiara Dwi., Bahari, Zakaria., and Hamat, Zahri. (2016). History of Islamic Bank in Indonesia: Issues Behind Its Establishment. International Journal of Finance and Banking Research. http://article.sciencepublishinggroup.com

Setiawan, B. (2013). Menganalisa Statistik Bisnis dan Ekonomi dengan SPSS 21. Yogyakarta: Andi

Setiawan, B. (2015). Teknik Praktis Analisis Data Penelitian Sosial \& Bisnis dengan SPSS. Yogyakarta: CV Andi Offset

http://ojk.go.id//kanal/syariah/tentang-syariah/pages/PBS-dan-Kelembagaan.aspx

http://www.portal-statistik.com/2014/02/one-smple-t-test-uji-t-satu-sampel.html

https://www.statistikian.com/2014/04/independen-t-test-dengan-spss.html 